\begin{tabular}{|c|c|c|c|}
\hline \multirow{3}{*}{ 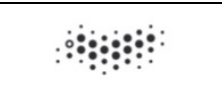 } & НАУЧНО-ТЕХНИЧЕСКИЙ ВЕСТНИК ИНФОР & ННЫХ ТЕХНОЛОГИЙ, МЕХАНИКИ И ОПТИКИ & \multirow{3}{*}{ 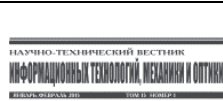 } \\
\hline & март-апрель 2015 & ISSN 2226-1494 http://ntv.ifmo.ru/ & \\
\hline & SCIENTIFIC AND TECHNICAL JOURNAL OF INF & ION TECHNOLOGIES, MECHANICS AND OPTICS & \\
\hline УНИВЕРСИ & March-April 2015 & http://ntv.ifmo.ru/en & \\
\hline
\end{tabular}

\title{
NON-INTRUSIVE GAS-PHASE THERMOMETRY FOR INDUSTRIAL OXY-FUEL BURNERS
}

\section{J.W. Tröger ${ }^{\mathrm{a}, \mathrm{b}}$, Th. Seeger ${ }^{\mathrm{a}, \mathrm{b}}$}

a Institute of Engineering Thermodynamics, University of Siegen, Siegen, 57076, Germany

${ }^{\mathbf{b}}$ Erlangen Graduate School in Advanced Optical Technologies (SAOT), University of Erlangen-Nuremberg, Erlangen, 91052, Germany

Corresponding author: johannes.troeger@uni-siegen.de

Article info

Received 23.01.15, accepted 25.02. 15

doi: $10.17586 / 2226-1494-2015-15-2-211-217$

Article in English

For citation: Tröger J.W., Seeger T. Non-intrusive gas-phase thermometry for industrial oxy-fuel burners. Scientific and Technical Journal of Information Technologies, Mechanics and Optics, 2015, vol.15, no. 2, pp. 211-217. (in English)

Abstract. The use of oxy-fuel combustion processes is of large interest for several industrial fields applications since it offers the advantages of low $\mathrm{NO}_{\mathrm{x}}$ emissions in combination with high combustion temperatures even without additional preheating. For optimization of such processes a detailed understanding based on precise experimental data is necessary. So far there is still a lack of precise experimental data achieved with high spatial and temporal resolution from industrial relevant turbulent oxy-fuel combustion processes. Beside species concentration information the gas phase temperature is of utmost importance for an improved understanding of the basic chemical reactions and the pollutant formation.

The coherent anti-Stokes Raman spectroscopy (CARS) technique is a very well suited laser based tool for a non-intrusive investigation of such turbulent high temperature combustion processes. In this work we analysed an industrial $400 \mathrm{~kW}$ oxy-fuel burner with the help of $\mathrm{O}_{2}$ based vibrational CARS system which is integrated in an industrial relevant test furnace. The burner is fed with pure oxygen and natural gas at an equivalence ratio of $\phi=0.9$. At one downstream position temporal and spatial resolved temperatures were measured along a $600 \mathrm{~mm}$ line. Additional air sucked in from the environment seems to influence the gas phase temperature significantly.

Keywords: vibrational coherent Anti-Stokes Raman scattering, spectroscopy, temperature measurement, oxy-fuel combustion, combustion diagnostic.

Acknowledgements. The authors gratefully acknowledge the AiF for funding the IGF work $17838 \mathrm{~N} / 4$ of the research association Gas- und Wärme-Institut Essen e.V.- GWI, Hafenstraße 101, 45356 Essen, Germany, in the framework of the industrial common research (IGF) of the Federal Ministry of Economics and Technology based on a resolution of the German Federal Parliament.

\section{ДИСТАНЦИОННЫЙ МЕТОД КОНТРОЛЯ ТЕМПЕРАТУРЫ ГАЗА ДЛЯ ПРОМЫШЛЕННЫХ КАМЕР СГОРАНИЯ И.В. Трёгер ${ }^{\mathrm{a}, \mathrm{b}}$, Т. Зеегер ${ }^{\mathrm{a}, \mathrm{b}}$}

${ }^{\mathrm{a}}$ Институт технологий термодинамики, Университет Зигена, Зиген, 57076, Германия

' Высшая школа передовых оптических технологий (SAOT), Университет Эрлангена-Нюрнберга, Эрланген, 91052 ,

Германия

Адрес для переписки: johannes.troeger@uni-siegen.de

Информация о статье

Поступила в редакцию 23.01 .15 , принята к печати 25.02 .15

doi: $10.17586 / 2226-1494-2015-15-2-211-217$

Язык статьи - английский

Ссылка для цитирования: Трёгер И.В., Зеегер Т. Дистанционный метод контроля температуры газа для промышленных камер сгорания // Научно-технический вестник информационных технологий, механики и оптики. 2015. Том 15. № 2. С. 211-217.

Аннотация. Применение процессов сгорания топлива в присутствии чистого кислорода представляет значительный интерес для многих отраслей промышленности благодаря низкому содержанию выделяемых оксидов азота $\mathrm{NO}_{x}$ при высоких температурах сгорания даже при отсутствии предварительного подогрева. Для оптимизации подобных процессов требуется ясное понимание их сущности, основанное на точных экспериментальных данных. В настоящее время отсутствуют точные результаты экспериментов с высоким временным разрешением, касающиеся турбулентных процессов сгорания топлива в промышленных установках. Помимо определения концентрации выбрасываемых веществ, огромное значение имеет информация о температуре сгорающего газа, позволяющая лучше понимать протекающие химические реакции и процессы формирования выбросов в атмосферу. 
Когерентная антистоксовская рамановская спектроскопия (CARS) - это отличный дистанционный лазерный метод исследования высокотемпературных турбулентных процессов сгорания топлива.

При помощи колебательной CARS системы с применением $\mathrm{O}_{2}$ исследована работа промышленной камеры сгорания на 400 кВт, сопряженной с соответствующей вспомогательной печью. В камеру сгорания подавался чистый кислород и природный газ в эквивалентном соотношении $\varphi=0,9$. Пространственно разнесенные температуры в нижнем потоке измерены на протяжении 600 мм. Установлено, что дополнительный подсос атмосферного воздуха может в значительной степени влиять на температуру газа.

Ключевые слова: колебательная когерентная антистоксовская рамановская спектроскопия, измерение температуры газа, сгорание топлива, диагностика процесса сгорания.

Благодарности. Авторы благодарят AiF за финансирование совместной прикладной исследовательской (IGF) paботы 17838 N / 4 Исследовательской ассоциации Института газа и теплоты, г. Эссен, e.V.- GWI, Hafenstraße 101, 45356 Essen, Germany, работа проводилась в рамках IGF Федерального министерства экономики и технологии на основе Постановления Федерального Парламента Германии.

\section{Introduction}

Combustion processes on an industrial scale in which oxygen instead of air is used as an oxidizer are getting more and more into focus. These so-called oxy-fuel combustion processes are of great interest. They are further developed, for instance, for the steel and the glass industry [1,2]. In the glass industry of the United States already more than $25 \%$ of all glass-melting furnaces are heated by such oxy-fuel combustion processes [3]. The expression "oxy-fuel combustion" is used in two different ways. In the area of power plant technology the aim is to prevent the release of large quantities of $\mathrm{CO}_{2}$ into the atmosphere. One possibility is to combust the fuel in an oxygen-carbon dioxide atmosphere $[4,5]$. By introducing an exhaust gas recirculation the exhaust gas, which is mostly consisting of carbon dioxide and water vapour is fed back into the combustion chamber to keep the temperature in the combustion chamber on a low level and to rise the amount of $\mathrm{CO}_{2}$. Thereby a significant increase of the carbon dioxide concentration can be reached which makes its removal from the exhaust gas more effective. This removed $\mathrm{CO}_{2}$ can be stored e. g. in depleted oil and gas fields which is the basic idea of carbon capture and storage (CCS). In the area of power plant technology the oxy-fuel combustion is one potential means of mitigating the contribution of fossil fuel emissions to global warming.

In thermal process engineering however the oxy-fuel combustion process is used to reach high combustion temperatures even without preheating. In this case the combustion of fuel with pure oxygen as an oxidizer is referred as oxy-fuel combustion. The application of such oxy-fuel burners shows some clear benefits compared to air breathing burners. The amount of $\mathrm{NO}_{\mathrm{x}}$ emissions of a pure oxygen combustion process is significantly lower, which is important in order to fulfil emission regulations. Additionally the combustion with pure oxygen leads to high temperatures without any costs for air preheating. As an example, the calculated adiabatic flame temperature for a stoichiometric methane-air flame $\left(\mathrm{p}=1 \mathrm{bar}, \mathrm{T}_{\text {surrounding }}=298 \mathrm{~K}\right)$ is approximately $2250 \mathrm{~K}$ compared to roughly $3050 \mathrm{~K}$ for the corresponding methane-oxygen flame [6]. Although this type of oxy-fuel combustion is increasingly applied in thermal process engineering, there is still a need for optimization. For such an optimization the species concentration information and the gas phase temperature is of utmost importance. These data can be used for a validation of numerical models and they are additionally necessary for an improved understanding of the basic chemical reactions and the pollutant formation.

Up to now there are only a few experimental investigations of such industrial relevant oxy-fuel processes available [7-9]. Nevertheless, there is still a need for precise experimental data achieved with high spatial and temporal resolution. These data could then also be used for a validation of numerical models. Such precise measurements in industrial relevant oxy-fuel processes like, e.g. in glass melting furnaces are challenging due to the high combustion temperature in combination with high turbulence. Here laser-based non-invasive measurement methods are in principle well suited to deliver the necessary information (see e.g. [10, 11]). Nevertheless, the presence of dust particles, high temperatures near the furnace due to radiation and the availability of only small optical accesses within a large furnace are still limiting the application of most laser based measurement techniques.

Coherent anti-Stokes Raman scattering technique (CARS) offers the possibility for precise temperature measurements in flames (see e.g. [12-14]). It has been developed and used now for some decades and is currently one of the best established non-intrusive thermometry tools in the field of combustion analysis. Several studies of different types of flames have proven its high capability [15-18]. Today, the CARS technique using the $\mathrm{N}_{2}$ molecule as a temperature indicator is routinely used even in harsh combustion environments such as IC engines, high-pressure burners and gas turbines [19-24]. In order to probe temperatures in a technical relevant combustion chamber, optical access is always restricted by the need for very small windows. Since CARS is a coherent technique, it has the advantage that only two, small, line-of sight windows are required to focus the laser beams into the probe volume and to collect the generated signal.

Therefore, in this work we present the application of a vibrational-CARS system for gas phase temperature measurements in large scale furnace equipped with a typical industrial oxy-fuel burner. Since in the oxy-fuel process no nitrogen is present, the $\mathrm{O}_{2}$ molecule was used as a temperature indicator. 


\section{Experimental}

\section{CARS setup}

Generally, in CARS the Raman transition of interest is excited resonantly by the frequency difference of two laser beams irradiating the sample, one narrowband e.g. a frequency doubled Nd:YAG $\left(\omega_{1}\right)$ and the other $\left(\omega_{2}\right)$, a broadband source, usually a dye laser or an optical parametric oscillator (OPO). The third laser beam $\left(\omega_{3}\right)$, normally from the same laser source as the first pump beam, is scattered from the excited Raman transitions and the signal is emitted in a coherent, laser-like beam at the anti-Stokes frequency of the probed species. This is schematically shown in Fig. 1. The species dependent CARS signal is generated at frequency $\omega_{\text {CARS }}=\omega_{1}-\omega_{2}+\omega_{3}$. The frequency difference between the pump beam $\omega_{1}$ and the Stokes beam $\omega_{2}$ has to match a Raman resonance of the molecule of interest which is used for the temperature determination. In air breathing flames $\mathrm{N}_{2}$ is usually used as a temperature indicator in the CARS process since it is inert. In an oxy-fuel process, however, there has to be used either $\mathrm{O}_{2}, \mathrm{CO}$ or $\mathrm{CO}_{2}$ as a temperature indicator. We used oxygen for the temperature determination since a lean oxy-fuel flame is investigated. Additionally, the vibrational CARS process for diatomic molecules is still easier to model and therefore such CARS signals are simpler to evaluate [25]. A detailed description of the CARS process can be found, e.g. in [10, 26].

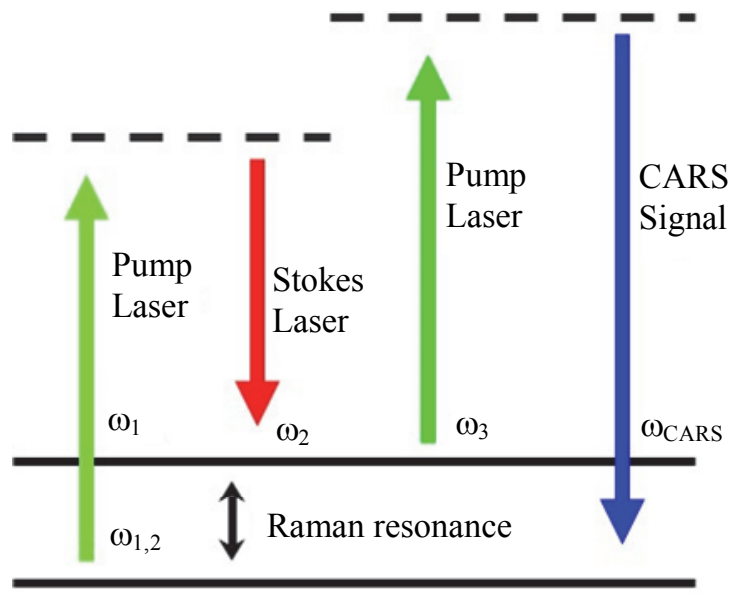

Fig. 1. Energy level diagram of the vibrational CARS process

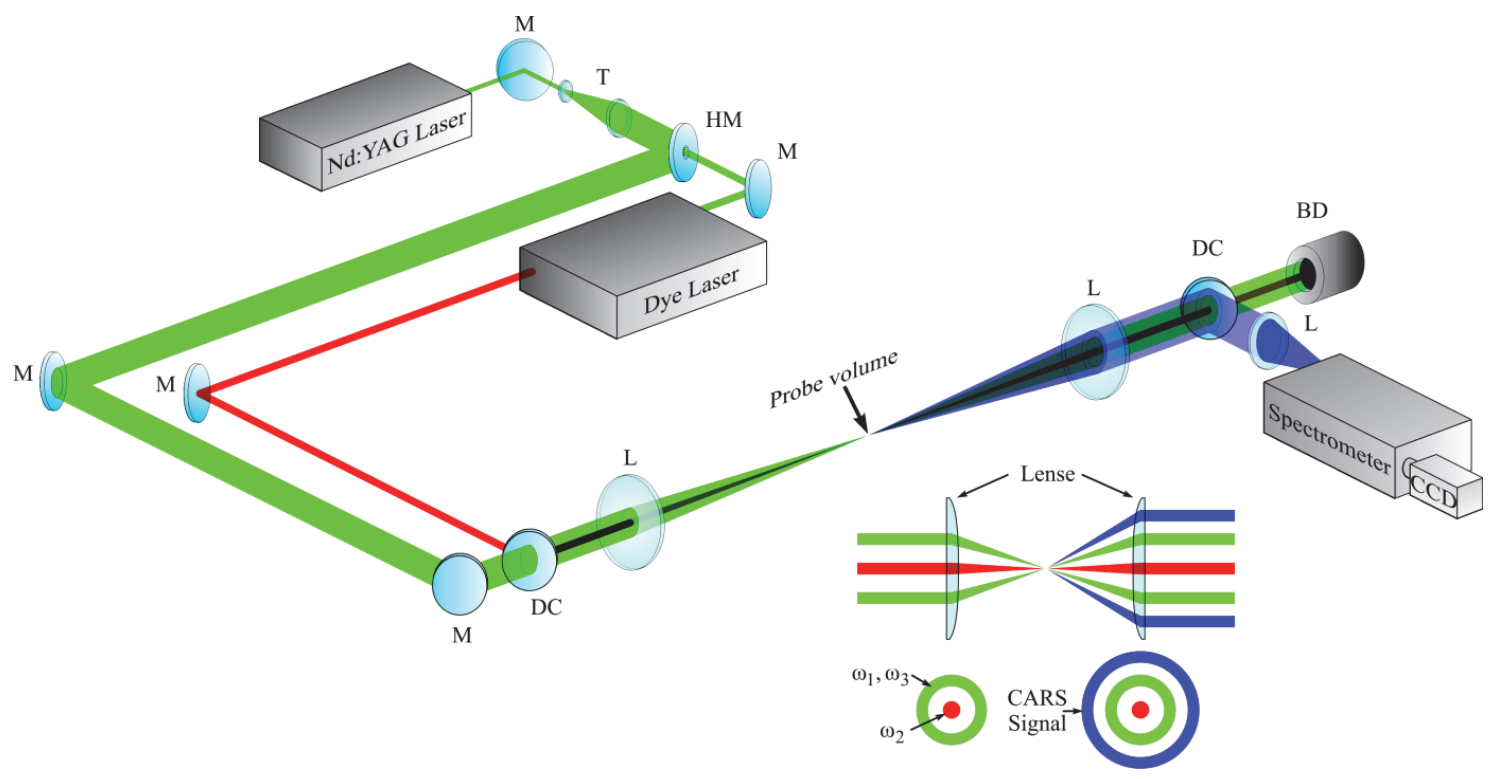

Fig. 2. Experimental CARS setup: M, mirror; T, telescope; HM, hole mirror; DC, dichroic mirror; L, lense; BD, beam dump; CCD, charge coupled devise camera

A schematic drawing of the experimental vibrational CARS setup is shown in Fig. 2. The laser system is based on a frequency doubled, injection-seeded Nd:YAG laser. The output power was $800 \mathrm{~mJ}$ at $532 \mathrm{~nm}$. The pulse duration is $8 \mathrm{~ns}$ and the repetition rate is $10 \mathrm{~Hz}$. This Nd:YAG laser provides in the CARS process the first and second pump laser beam $\left(\omega_{1}, \omega_{3}\right)$. Part of the $532 \mathrm{~nm} \mathrm{Nd}$ :YAG laser output is used to pump a commercial broadband dye laser at a central wavelength of $580 \mathrm{~nm}$. The dye laser was equipped with a mixture of Rhodamine 6G and Rhodamine B in ethanol. The dye laser acts in the CARS process as the Stokes laser $\left(\omega_{2}\right)$ and 
these two dyes were mixed to match the vibrational Raman resonance of oxygen. The laser beams were overlapped in a USED CARS geometry [27]. Here the dye laser beam is centred inside the donut shaped Nd:YAG laser beam. The donut shaped Nd:YAG laser beam is generated by a high reflecting mirror (HM) with a central hole (see Fig. 2). In this configuration both laser beams will face the same density changes inside the large furnace and the influence of beam steering is minimized. The laser beams are focused into the probe volume and collimated afterwards by lenses with a focal length of $2500 \mathrm{~mm}$. The resulting measurement volume was determined to be approximately $3.5 \mathrm{~mm}$ in length and $150 \mu \mathrm{m}$ in diameter. For the dye laser a power of $10 \mathrm{~mJ}$ and for the Nd:YAG laser $25 \mathrm{~mJ}$ was measured in the probe volume. The $\mathrm{O}_{2}$ CARS signal occurring at $491 \mathrm{~nm}$ was separated from the laser beams by dichroic mirrors (DC) and focussed on the entrance slit of a spectrometer. The detection system consists of a spectrometer with a focal length of $550 \mathrm{~mm}$ and a grating consisting of 2400 lines $/ \mathrm{mm}$. The CARS signal was detected by a charge coupled device (CCD) camera. At each measurement position 1000 single shot spectra were recorded and evaluated using in house developed CARS code [28]. To take line narrowing into account, the theoretical vibrational CARS spectra were calculated by use of the modified exponential gap law [29]. The parameters for $\mathrm{O}_{2}$ were taken from Huber at al. and Rouille at al. $[30,31]$.

\section{Burner setup}

The oxy-fuel burner was mounted inside a large test furnace which is shown schematically in Fig. 2. The furnace has a width of $1000 \mathrm{~mm}$ and a length of $5000 \mathrm{~mm}$. Temperature measurements were performed at different positions along a horizontal line as marked in Fig. $31500 \mathrm{~mm}$ downstream the burner exit. Due to the axial symmetry the probe volume positions have to cover only half of the combustion chamber. For these CARS measurements two opposite holes in the wall of the combustion chamber were used for the incoming laser beams and for the signal detection. The diameter of the hole for the incoming laser beam was $60 \mathrm{~mm}$. The hole on the opposite site was concentric with an inner diameter of $250 \mathrm{~mm}$ facing the combustion chamber. The outer diameter was $60 \mathrm{~mm}$. The measurements were performed without optical windows. For these first measurements a downstream position of $1500 \mathrm{~mm}$ was chosen in order to investigate a region where chemical reactions take place.

The industrial diffusion type oxy-fuel burner had a maximum available thermal power of $400 \mathrm{~kW}$. Two independent gas supplies, one for natural gas and one for oxygen were connected to this diffusion burner. Mass flow controllers were used to adjust the flow rates for both gases. A flow rate of $40 \mathrm{Nm}^{3} / \mathrm{h}$ was set for natural gas and an equivalence ratio of $\phi=0.9$ was used in the experiments shown in this work.

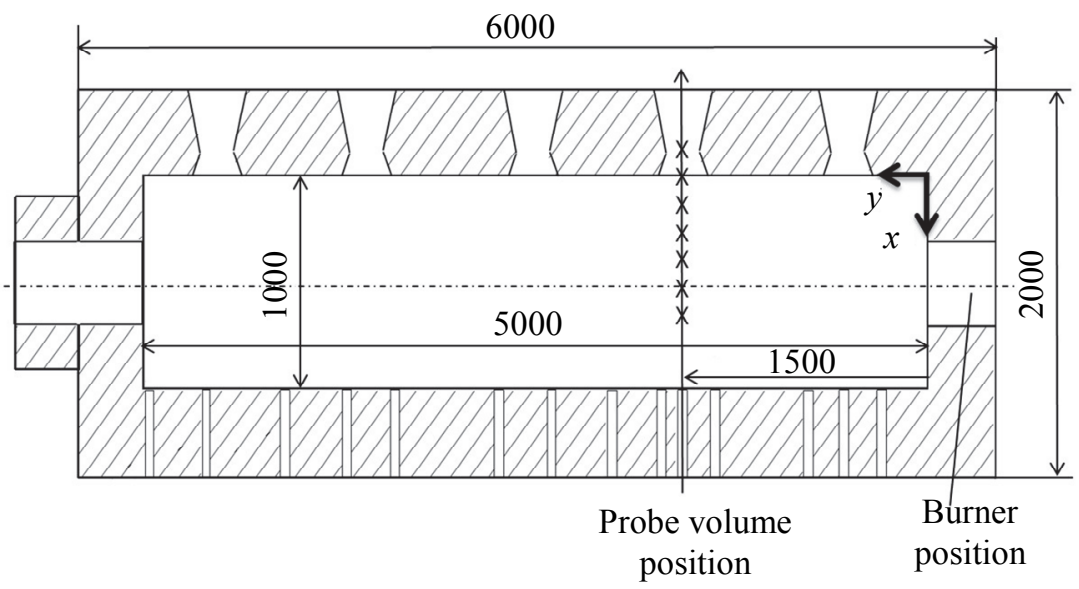

Fig. 3. Sketch of the furnace equipped with the oxy-fuel burner. The probe volume positions of the CARS measurements are marked $(x)$

\section{Results and Discussion}

The temperature results achieved along the line $1500 \mathrm{~mm}$ downstream of the burner are shown in Fig. 4 . Measurements were taken each $40 \mathrm{~mm}$. The mean temperature and the standard deviation for 1000 single shot measurements are shown in Fig. 4, a. It should be noted that nearly at all measurement positions a large number of spectra could be evaluated. In maximum only less than $21 \%$ of the CARS spectra have to be sorted out probably due to beam steering effects or dust particles.

The points at $x=-50 \mathrm{~mm}$ and $x=-30 \mathrm{~mm}$ were taken in the concentric hole within the chamber wall and a mean temperature of about $1000 \mathrm{~K}$ was evaluated. The highest mean temperature of $1787 \mathrm{~K}$ was measured at $x=270 \mathrm{~mm}$. The temperature is decreasing towards the centre. At $x=510 \mathrm{~mm}$ a mean temperature of $1293 \mathrm{~K}$ was achieved. Obviously in this part of the furnace the flame is slightly shifted to one side. This is also confirmed by the standard deviation. As an example in Fig. 4, b-d, scatter plots of the single shot temperatures are shown. The corresponding probably density distributions are displayed in Fig. 4, e-g. Due to the high turbulence of this oxy-fuel combustion process a large shot to shot variation of the temperature can be observed. 
At $x=270 \mathrm{~mm}$ a gas temperature between $727 \mathrm{~K}$ and $2697 \mathrm{~K}$ and a corresponding large standard deviation of $385 \mathrm{~K}$ was measured. Only a small part of the temperature fluctuation is caused by the sensor system. In prior laboratory tests with a McKenna burner in a laminar premixed CO flame a standard deviation of around $100 \mathrm{~K}$ at a mean flame temperature of $2000 \mathrm{~K}$ was observed. This is typical for a vibrational CARS sensor and comparable values have been found for CARS systems using $\mathrm{N}_{2}$ as temperature indicator [32]. Nevertheless the achieved gas phase temperatures are lower than the adiabatic flame temperature of $3051 \mathrm{~K}$ for the oxy-fuel flame investigated here. This can be explained by additional air sucked into the combustion chamber due to a pressure difference of -0.08 bar to the environment.

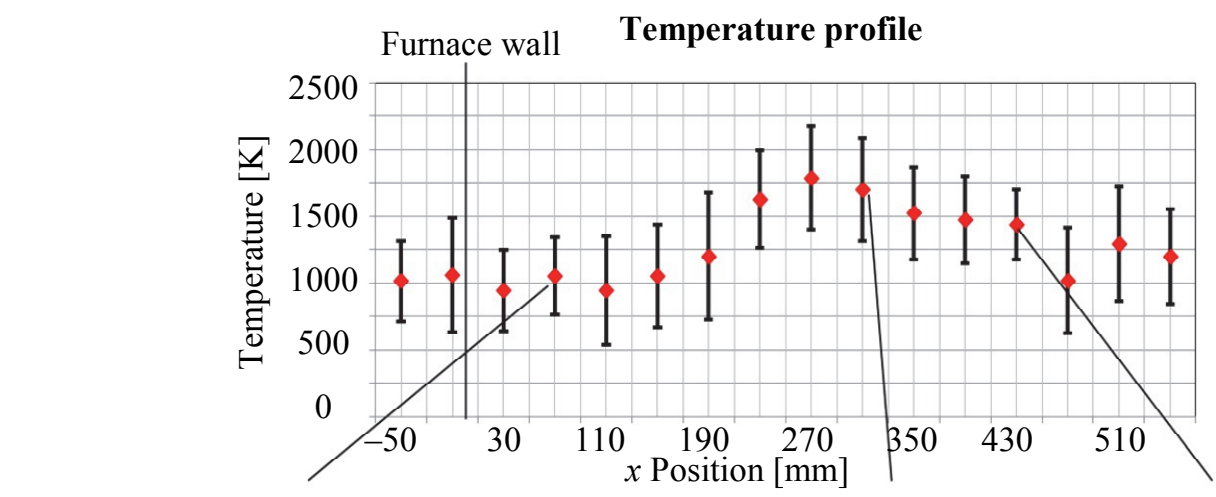

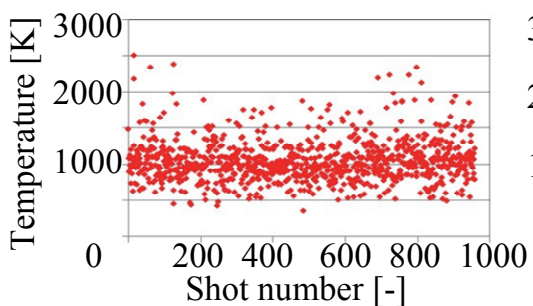

b

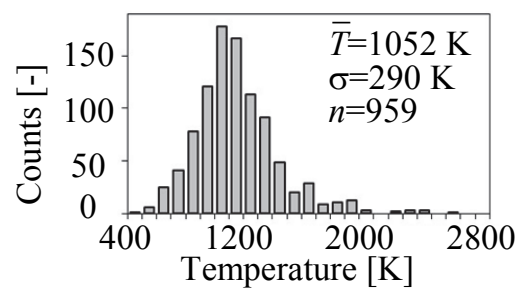

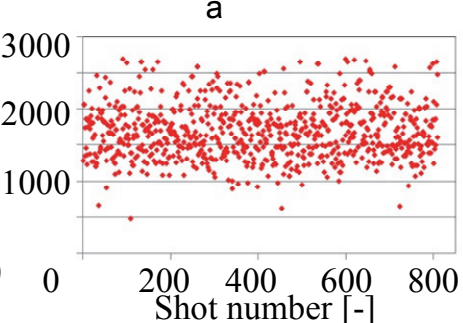

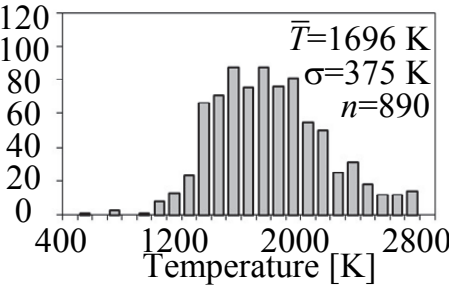

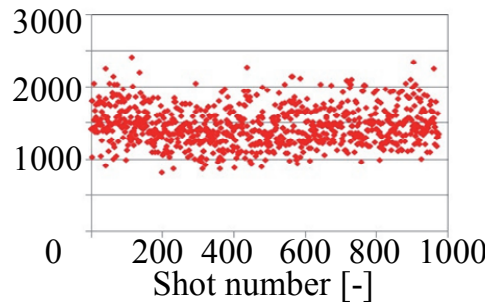

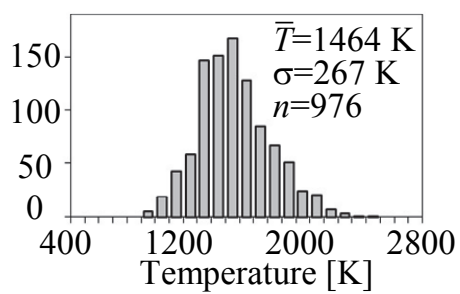

Fig. 4. Temperature profile taken along a line $1500 \mathrm{~mm}$ downstream of the burner position (a); Scatter plots for selected measurement positions $(b-d)$;

Probably density distributions for the same selected probe volume positions $(\mathrm{e}-\mathrm{g})$

As an example in Fig. 5 evaluated single shot spectra are shown together with the best fitting theoretical spectrum. The normalized experimental spectra were compared against a library of theoretically calculated vibrational CARS spectra using a least-squares contour-fitting method. The evaluation procedure interpolates between the precalculated spectra of varying temperatures in the library by means of cubic splines using the Levenberg-Marquardt algorithm. It can be seen from Fig. 5 that the fit quality is quite good for the complete temperature range of interest.

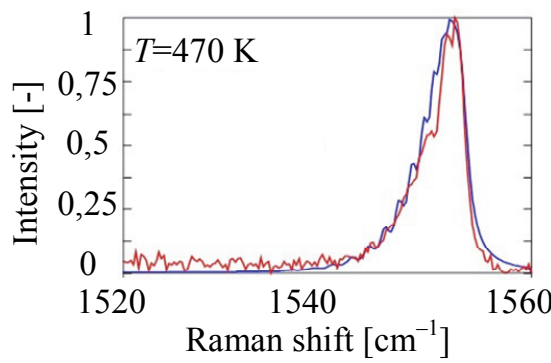

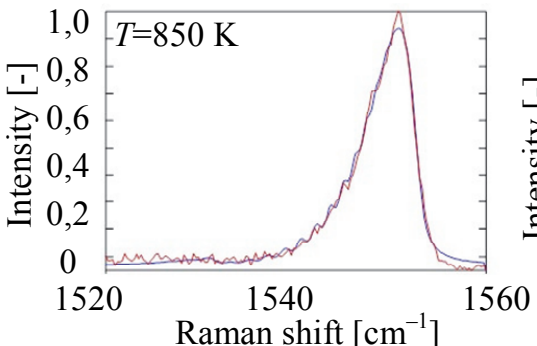

experiment

theory

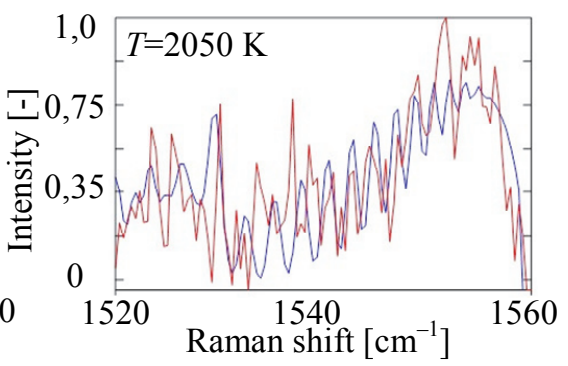

Fig. 5. Selected single shot spectra taken at $x=550 \mathrm{~mm}$ shown together with the best fitting theoretical spectrum 


\section{Summary}

For the first time temporally and spatially resolved $\mathrm{O}_{2}$ vibrational CARS temperature measurements in a furnace equipped with an industrial relevant oxy-fuel burner were performed successfully. The results show that the developed $\mathrm{O}_{2}$ vibrational CARS sensor is well suitable for a non-invasive investigation of such combustion processes. A temperature profile along a line for a fixed downstream position was evaluated from single shot temperature measurements. The corresponding scatter plots show the turbulent behaviour of this oxy-fuel diffusion flame.

\section{References}

1. Maclean S., Leicher J., Giese A., Irlenbusch J. NOx-arme Nutzung von Oxy-fuel-verbrennung mit stark $\mathrm{N}_{2}$ haltigem Sauerstoff in der NE-Metallurgie // GWI - Gaswärme International. 2012. V. 61. P. 85-92.

2. Al-Chalabir R., Schatz C., Yap L., Marshall R. Flat flame oxy-fuel burner technology for glass melting // Ceramic Engineering and Science Proceedings. 1995. V. 16. N 2. P. 202-215.

3. Ross C.P., Tincher G.L., Rasmussen M. Glass melting technology: a technical and economic assessment, glass manufacturing industry // U.S. Department of Energy-Industrial Technologies Program, 2004. N DEFC-36-021D14315.

4. Kluger F., Mönckert P., Wild T., Marquard A., Levasseur A.A. Entwicklungsstand der oxy-fuelverbrennungstechnologie / In: Kraftwerkstechnisches Kolloquium 2010 - Kraftwerkstechnik.

5. Kuckshinrichs W., P Markewitz., Linssen J., Zapp P., Peters M., Köhler B., Müller T.E., Leitner W. Weltweite innovation bei der entwicklung von CCS-technologien und möglichkeiten der nutzung des recyclings von $\mathrm{CO}_{2} / /$ Study on Behalf of the Federal Ministry of Economy and Energy. 2010. N 25/08 AZ | D4-020815.

6. Warnatz J., Maas U., Dibble R.W. Combustion: Physical and Chemical Fundamentals, Modeling and Simulation, Experiments, Pollutant Formation. Berlin: Springer, 2001. 378 p. doi: 10.1007/978-3-540-45363-5

7. Lallemant N., Breussin F., Weber R. Analysis of the flame structure, heat transfer and NOx emission characteristics of oxy-natural gas flames // International Flame Research Foundation. 1998. Doc N F85/y/7.

8. Lallemant N., Dugué J., Weber R. Analysis of the experimental data collected during the OXYFLAM-1 and OXYFLAM-2 experiments // International Flame Research Foundation. 1997. N F85/Y/4.

9. Lallemant N., Dugué J., Weber R. Measurement techniques for studying oxy-natural gas flames // Journal of the Institute of Energy. 2003. V. 76. N 507. P. 38-53.

10. Eckbreth A.C. Laser Diagnostics for Combustion Temperature and Species. Amsterdam: Gordon and Breach Publishers, 1996. $632 \mathrm{p}$.

11. Kohse-Höinghaus K. Applied Combustion Diagnostics. NY: Taylor \& Francis, 2002. 672 p.

12. Kampmann S., Seeger T., Leipertz A. Simultaneous coherent anti-Stokes Raman scattering and twodimensional laser Rayleigh thermometry in a contained technical swirl combustor // Applied Optics. 1995. V. 34. N 15. P. 2780-2786.

13. Beyrau F., Datta A., Seeger T., Leipertz A. Dual-pump CARS for the simultaneous detection of $\mathrm{N}_{2}, \mathrm{O}_{2}$ and $\mathrm{CO}$ in $\mathrm{CH}_{4}$ flames // Journal of Raman Spectroscopy. 2002. V. 33. N 11-12. P. 919-924.

14. Braeuer A., Beyrau F., Weikl M.C., Seeger T., J Kiefer., Leipertz A., Holzwarth A., Soika A. Investnigation of the combustion process in an auxiliary heating system using dual-pump CARS // Journal of Raman Spectroscopy. 2006. V. 37. N 6. P. 633-640. doi: 10.1002/jrs.1489

15. Magre P., Aguerre F., Collin G., Versaevel P., Lacas F., Rolon J.C. Temperature and concentration measurements by CARS in counterflow laminar diffusion flames // Experiments in Fluids. 1995. V. 18. N 5. P. 376-382. doi: 10.1007/BF00211395

16. Brackmann C., Bood J., Bengtsson P.-E., Seeger T., Schenk M., Leipertz A. Simultaneous vibrational and pure rotational coherent anti-Stokes Raman spectroscopy for temperature and multispecies concentration measurements demonstrated in sooting flames // Applied Optics. 2002. V. 41. N 3. P. 564-572.

17. Beyrau F., Seeger T., Malarski A., Leipertz A. Determination of temperatures and fuel/air ratios in an etheneair flame by dual-pump CARS // Journal of Raman Spectroscopy. 2003. V. 34. N 12. P. 946-951. doi: 10.1002/jrs. 1092

18. Datta A., Beyrau F., Seeger T., Leipertz A. Temperature and CO concentration measurements in a partially premixed $\mathrm{CH}_{4} /$ Air coflowing jet flame using coherent Anti-Stokes Raman scattering // Combustion Science and Technology. 2004. V. 176. N 11. P. 1965-1984. doi: 10.1080/00102200490504607

19. Weikl M.C., Beyrau F., Leipertz A. Simultaneous temperature and exhaust-gas recirculation-measurements in a homogeneous charge-compression ignition engine by use of pure rotational coherent anti-Stokes Raman spectroscopy // Applied Optics. 2006. V. 45. N 15. P. 3646-3651. doi: 10.1364/A0.45.003646

20. Brackmann C., Bood J., Afzelius M., Bengtsson P.-E. Thermometry in internal combustion engines via dualbroadband rotational coherent anti-Stokes Raman spectroscopy // Measurement Science and Technology. 2004. V. 15. N 3. P. R13-R25. doi: 10.1088/0957-0233/15/3/R01 
21. Clauss W., Klimenko D.N., Oschwald M., Vereschagin K.A., Smirnov V.V., Stelmakh O.M., Fabelinsky V.I. CARS investigation of hydrogen Q-branch linewidths at high temperatures in a high-pressure $\mathrm{H}_{2}-\mathrm{O}_{2}$ pulsed burner // Journal of Raman Spectroscopy. 2002. V. 33. N 11-12. P. 906-911.

22. Hussong J., Lückerath R., Stricker W., Bruet X., Joubert P., Bonamy J., Robert D. Hydrogen CARS thermometry in a high-pressure $\mathrm{H}_{2}$-air flame. Test of $\mathrm{H}_{2}$ temperature accuracy and influence of line width by comparison with $\mathrm{N}_{2}$ CARS as reference // Applied Physics B: Lasers and Optics. 2001. V. 73. N 2. P. 165172.

23. Switzer G., Sturgess G., Sloan D., Shouse D. Relation of CARS temperature fields to lean blowout performance in an aircraft gas turbine generic combustor // AIAA paper 94-3271. 1994.

24. Meyer T.R., Roy S., Lucht R.P., Gord J.R. Dual-pump dual-broadband CARS for exhaust-gas temperature and $\mathrm{CO}_{2}-\mathrm{O}_{2}-\mathrm{N}_{2}$ mole-fraction measurements in model gas-turbine combustors // Combustion and Flame. 2005. V. 142. N 1-2. P. 52-61. doi: 10.1016/j.combustflame.2005.02.007

25. Reichardt T.A., Schrader P.E., Farrow R.L. Comparison of gas temperatures measured by coherent antiStokes Raman spectroscopy (CARS) of $\mathrm{O}_{2}$ and $\mathrm{N}_{2} / /$ Applied Optics. 2001. V. 40. N 6. P. 741-747.

26. Seeger T. Moderne Aspekte der linearen und nichtlinearen Raman-Streuung zur Bestimmung thermodynamischer Zustandsgrößen in der Gasphase. Habilitation, University of Erlangen-Nuremberg, 2006.

27. Eckbreth A.C., Dobbs G.M., Stufflebeam J.H., Tellex P.A. CARS temperature and species measurements in augmented jet engine exhausts // Applied Optics. 1984. V. 23. N 9. P. 1328-1339.

28. Magens E. Nutzung von Rotations-CARS zur Temperatur- und Konzentrationsmessung in Flammen. Dissertation, University of Erlangen-Nuremberg, 1993.

29. Rahn L.A., Palmer R.E., Koszykowski M.L., Greenhalgh D.A. Comparison of rotationally inelastic collision models for Q-branch Raman spectra of $\mathrm{N}_{2}$ // Chemical Physics Letters. 1987. V. 133. N 6. P. 513-516. doi: 10.1016/0009-2614(87)80069-6

30. Herzberg G. Molecular Spectra and Molecular Structure. $2^{\text {nd }}$ ed. D. van Nostrand Company, Inc., 1963.

31. Rouillé G., Millot G., Saint-Loup R., Berger H. High-resolution stimulated Raman spectroscopy of $\mathrm{O}_{2} / /$ Journal of Molecular Spectroscopy. 1992. V. 154. N 2. P. 372-382. doi: 10.1016/0022-2852(92)90215-A

32. Thumann A., Seeger T., Leipertz A. Evaluation of two different gas temperatures and their volumetric fraction from broadband $\mathrm{N}_{2}$ coherent anti-Stokes Raman spectroscopy spectra // Applied Optics. 1995. V. 34. N 18. P. 3313-3317. doi: 10.1364/AO.34.003313

Johannes W. Tröger

Thomas Seeger

Трёгер Иоганнес В.

Зеегер Томас
- $\quad$ scientific assistant, Institute of Engineering Thermodynamics, University of Siegen, 57076, Siegen, Germany; scientific assistant, Erlangen Graduate School in Advanced Optical Technologies (SAOT), University of Erlangen-Nuremberg, Erlangen, 91052, Germany, johannes.troeger@uni-siegen.de

- D.Sc., Professor, Mentor, Institute of Engineering Thermodynamics, University of Siegen, Siegen, 57076, Germany; Professor, Mentor, Erlangen Graduate School in Advanced Optical Technologies (SAOT), University of Erlangen-Nuremberg, Erlangen, 91052, Germany, Thomas.Seeger@uni-siegen.de

- научный сотрудник, Институт технологий термодинамики, Университет Зигена, Зиген, 57076, Германия; научный сотрудник, Высшая школа передовых оптических технологий (SAOT), Университет Эрлангена-Нюрнберга, Эрланген, 91052, Германия, johannes.troeger@uni-siegen.de

- доктор технических наук, профессор, руководитель института, Институт технологий термодинамики, Университет Зигена, Зиген, 57076, Германия; профессор, руководитель, Высшая школа передовых оптических технологий (SAOT), Университет Эрлангена-Нюрнберга, Эрланген, 91052, Германия, Thomas.Seeger@uni-siegen.de 